УДК 177.3

DOI 10.35423/2078-8142.2021.2.1.5

Д. В. Усов,

доктор філософських наук, професор, Черкаський інститут пожежної безпеки імені Героїв Чорнобиля Національного університету циивільного захисту України,

м. Черкаси, Україна e-mail:dimausov@i.ua ORCID: https://orcid.org/0000-0002-8898-9743

\title{
ФІЛОСОФІЯ СВОБОДИ ТОМАСА ГОББСА: ЗАСАДНИЧІ СКЛАДОВІ ТА НОВІТНІ КОНТЕКСТИ
}

Автор статті виходить з того, щуо філософія Томаса Гоббса не втрачає своєї актуальності. Саме життя за доби «вірусократії», боротьби як за безпеку, так $i$ за свободу, потребує відповідей на питання про співвідношення прав, свободи, страху, безпеки, тобто тих проблем, до яких постійно звертався Томас Гоббс. Означені аспекти філософської спадщини Гоббса стануть предметом даної статі та поглиблять роздуми вітчизняних дослідників про сенс ідеї суспільного угоди Гоббса $і$ закладених у ній ще малодосліджених алгоритмів формування справедливої правової держави. Адже саме з політичної філософії Гоббса розпочинається притаманне модерній політичній філософії та філософії права глибинне зрушення в розумінні природи людини та ії свободи. Запропонована Гоббсом політична антропологія виходить з тези про природну рівність людей, а також з прагнення обтрунтувати необхідність усвідомлення індивідом обмеження власного егоїзму та свободи заради колективної волі інших громадян. Йдеться також про актуальність для сучасної філософії та намого вітчизняного простору розробленого Гоббсом принщипу суспільної угоди як нового суспільного принципу регуляції людського буття, який став втіленням істотного переходу від телеологічних до правових уявлень про людину, ї̈ свободу та справедливість. У політичній філософії Т. Гоббса було розроблено ідею про внутрішню непокору, свободу совісті як «права людини і громадянина», про те, щчо державна 
влада мусить визнавати, а не просто дозволяти персональну незалежність своїх громадян, їх права діяти на власний розсуд. Проте для подальшого розвитку изієї ідеї потрібно було вийти за межі філософії Т. Гоббса, шуо й судилося зробити Ж.-Ж. Руссо.

Ключові слова: Т. Гоббс, політична філософія, теорія суспільної угоди, свобода, безпека, страх, громадянське суспільство, Ж.-.Ж. Руссо.

Через глибинні дослідження (насамперед, у «Левіафані», що цього року відзначає 370-річчя) в царині принципу суспільної угоди як нового суспільного принципу регуляції людського буття, що став втіленням істотного переходу від телеологічних до правових уявлень про людину, iii свободу та справедливість, до роздумів Гоббса звертаються майже всі відомі в царині європейської політичної філософії автори. Вони наголошують на тому, що виявлений Гоббсом розрив із природним станом означає новий суспільний принцип регуляції діяльності - коли місце інстинктів та традиції може заступати справедливість. А індивід з усіма своїми природними правами погоджується зі спільнотою лише за умов існування таких правил, які виражають загальний інтерес. Ця модерна ідея суспільної угоди, втілена також у політичній філософії Ж.-Ж. Руссо, була розвинута згодом в тезі І. Канта про те, що в практичних питаннях, які стосуються виправдання норм та дій, місце змістовних принципів, таких як природа чи Бог, заступає формальний принцип розуму. На важливості цієї тези для філософії Т. Гоббса наголошував свого часу і К. Шмітт. Проте сьогодення знов і знов потребує осмислення співвідношення свободи, справедливості, страху, безпеки, тобто тих проблем, до яких постійно звертався Томас Гоббс. Послідовна реконструкція них і стане предметом даної статті, адже започатковані Т. Гоббсом у його політичній філософії принципові зрушення в тлумаченні природи людини, іiі свободи та справедливості знайшли своє продовження в багатьох сучасних філософських дискурсах. Йдеться передусім про праці таких відомих теоретиків, як Ю. Габермас, А. Гонет, О. Гьофе. А засаднича проблема Гоббсової політичної філософії про те, що є кращим для людини: мати необмежену свободу разом 
3 постійною небезпекою стати жертвою чужого свавілля, в дні сучасності перетворилася на теоретичні та практичні пошуки відповіді на запитання: що краще: хворіти, вмирати та жити вільно (чи навіть свавільно), чи йти на певні обмеження своїх прав і свобод заради здоров'я та життя?

До роздумів Гоббса про свободу та способи приборкання безмежного людського егоїзму звертається в другому томі своєї останньої фундаментальної роботи Ю. Габермас [1, с. 141-151]. На його думку, без Гоббса цілісна картина європейського філософського дискурсу розважливої свободи не буде довершеною. Політичній філософії Т. Гоббса насправді належить особливе місце не лише в історії політичної думки [2], а й безпосередньо в новітніх дослідженнях 3 проблеми свободи. Яскравим прикладом означеної тези постає праця А. Гонета «Про право свободи» [3], особливо іiі розділ «Негативна свобода та іiі конструкція свободи» [3, с. 44-57]. Фундаментом визначення поняття негативної свободи для Гонета постає вислів Т. Гоббса про свободу як відсутність зовнішнього спротиву [3, с. 44]. Важливою особливістю свободи негативної (як права діяти до межі, за якою порушуються права інших громадян) є й відповідна до неї концепція справедливості, в межах якої «свобода окремого індивіда об'єднується 3 прагненням до взаємодії, кооперації з іншими індивідами» [3, с. 55].

У контексті аналізу новітньої літератури, присвяченої філософії Т. Гоббса, та актуальної саме для українського соціального простору, важливою постає також стаття Л. фон Акельдорна «Про особу і офіс суверена в «Левіафані» Гоббса» [4]. Вона стосується суверена, його дій як «звичайної особи» та дій, які суверен здійснює в якості політика як штучної персони, яка в керівному офісі уособлює державу. Запропонована автором інтерпретація «Левіафана» Т. Гоббса постала розвитком ідеї щодо можливості конституційного обмеження дій суверена (державного апарату), продовженням актуальної дискусії про взаємини суверенітету особи суверена та громадянської спільноти.

Слід також виокремити в якості особливо значущої і працю О. Гьофе про Гоббса [5], де викладено не лише життєвий шлях та основні ідеї «енциклопедичних творів» Т. Гоббса, а й сучасні дискусії щодо політичної філософії останнього, а також досліджено 
основні поняття та принципи політичної антропології Гоббса: від його образу людини до філософії влади. Особливе місце в дослідженні посідає «Левіафан» Гоббса та його праця «Про громадянина», щодо роздумів про владу, справедливість та свободу як осердя політичної філософії. Як зазначає О. Гьофе, варто говорити про істотну антропологічну складову сучасної політичної філософії та іiі засадничої проблеми - проблеми справедливості. У цьому контексті саме Гоббс започаткував пошук відповіді на питання: «Чи існують насправді такі природні інтереси (i, відповідно, інтереси людства), які свідчили б на користь, чи навпаки - проти, соціальних, а точніше - політичних, тобто формоутворювальних щодо держави та права, повноважень на примус?» [6, с. 203]. Тому антропологія політична $є$ осердям антропології філософської, бо уможливлює розуміння засадничих для людського буття проблем справедливості та свободи. Завдяки творам Гоббса виявилась сутність (та хибність спрощених тлумачень спадщини останнього) взаємозв'язку кооперативного та конфліктного образів людини.

Суспільна угода стала для Гоббса синонімом домовленості індивідів щодо стійкого державного порядку, спроможного врятувати людей від жахів «природного стану» з його «війною всіх проти всіх». Трагічна картина самотнього, бідного та короткочасного людського життя, властиве індивіду в його «первісному стані» почуття страху та взаємної небезпеки і породжує, на думку Гоббса, можливість угоди індивідів щодо припинення «війни всіх проти всіх» та досягнення громадянського миру. Як зазначає відомий дослідник теорії суспільної угоди Т. Гоббса В. Керстінг: «абсолютне панування постає не лише достатньою умовою, а також і необхідною умовою для припинення стану війни і запровадження мирного порядку співіснування» [7, с. 100].

У теорії суспільної угоди Т. Гоббса йдеться про те, що кожна «маленька» людина є витоком як персональної, так і інституційної свободи та справедливості, укладаючи передусім угоду із собою, зі своїми прагненнями та сумлінням, а вже потім з іншими людьми та державою. А держава, своєю чергою, повинна виконувати роль механізму, який знаходить своє «право» і свою «істину» тільки в собі самому. Потреба всебічного осмислення соціального, політичного 
буття людини зумовлене також і пошуком шляхів опосередкування основних вимірів регулювання поведінки індивіда вже в громадянському суспільстві - особистої, персональної можливості домовитися щодо відмови від агресивної поведінки. Взаємний інтерес надає також можливість продовження дії спочатку лише простої мирної угоди в межах держави, де індивід змушений жертвувати правом та частиною свободи, спираючись на здатність розрізнення добра та зла. Проте тут виникає актуальна і до сьогодні проблема поєднання свободи та справедливості, власного та загального інтересу, що є додатковим аргументом на користь послідовної критичної реконструкції відповіді Гоббса на означене запитання. Адже в самій ідеї суспільної угоди, яка лежить в основі всіх суспільних угод та виконує роль засадничої легітимації, вкорінені основні проблеми сучасної політичної філософії, які можна сформулювати не лише як дилему кооперації чи конфлікту, або ж щастя чи свободи.

Завдяки Гоббсу ми не лише можемо, а й мусимо постійно стверджувати, що жодна людина навіть під страхом смерті не може думати інакше, ніж іiі переконує власний розум. А звідси випливає ідея дослідника про зовнішню покору при непокорі внутрішній, що має привести філософа і згодом приводить до ідеї свободи совісті як «права людини і громадянина», до розуміння індивідуальної незалежності, яка $є$ не лише дозволеною, а має бути й визнаною державною владою.

Найвідоміший твір Гоббса починається розділом про людину, іiі пристрасті та чесноти, що має істотний не лише методологічний, а й соціально-практичний зміст. Людина в його «Левіафані» та інших творах є одночасно і сильною, і слабкою, а іiі образ та життя постають органічно пов'язаними між собою. Завдяки послідовникам, плідні зерна його роздумів не були знищені разом зі своєю добою, а досить успішно дожили до наших днів: зла, агресивна людина потребує сильної держави, як тільки вона спрямовується на краще, стає здібною проявити своє духовне, божественне начало, то й держава стає не такою жорстокою. Таким чином, осердям гоббсівського розуміння людини стає ідея про те, що людина, отримавши державу, може і мусить (вже в суспільному стані) прагнути стати «схожою на Бога»: «Іноді людина бажає знати резуль- 
тат якоїсь дії; і тоді вона думає про якусь подібну дію в минулому та про наслідки, до яких ця дія призвела, гадаючи, що схожі призводять до схожих наслідків. Такий тип думки називається передбачення та розсудливість, чи передбачливість, а іноді - мудрість» [8, c. 81].

Розмірковуючи про любов та ненависть, Гоббс показує їх відмінність, яка полягає в наявності чи відсутності предмету пристрасті. Добро і зло також пов'язані між собою, не випливають 3 природи самих об'єктів, а залежать від людини, яка предмет свого прагнення називає добром, «натомість об’єкт своєї ненависті та відрази вона називає злом, а об'єкт своєї зневаги - низьким i дріб'язковим» [8, с. 100]. Ці тези Гоббс не лише доповнює визначенням трьох видів добра та зла, а й відзначає, що «будь-які прагнення, бажання й любов супроводжуються більшою чи меншою насолодою, а всілякі ненависть та відраза - більшим чи меншим незадоволенням та неприємністю» [8, с. 101]. Можна також стверджувати, що означені Гоббсом негативні якості людини, особливо помітні саме в час безсоромного накопичення первісного капіталу, $\epsilon$ принципово актуальними для сьогодення. Йдеться про користолюбство, яке завжди має відтінок ганебності, та честолюбство, як бажання посади та відзнак. Проте, визначаючи марнославство, Гоббс не забуває про славу як усвідомлення власної сили та здібностей та опертя на них. Коли ж упевненість у собі «грунтується на підлабузництві інших або ж тільки передбачається нею заради насолоди від думки про славу, тоді вона називається марнославством» [8, с. 104]. Важливими, за умов перехідної доби, є відсутність співчуття та солідарності, чеснот, які є наслідком та засадою справедливості: зневагу до інших людей можна вважати жорстокістю, яка походить від упевненості у власній персоні, а поєднання засмученості людини через багатство та шану інших людей з намаганням знищити суперника чи стати йому на перешкоді - ось що таке заздрість.

Перед тим як окреслити щастя як істотну (разом зі свободою) складову фундаментальних питань політичної філософії, Гоббс зупиняється на таких чеснотах, як чесність та гідність, а вже потім окреслює первісно-конститувальний сенс вічного і невпин- 
ного бажання людиною дедалі більшої влади. Тож, «гідність людини - річ відмінна від іiі вартості чи цінності, а також від іiі заслуг і полягає в особливій спроможності чи здібності до того, гідною чого цю людину вважають» [8, с. 132]. Визначаючи щастя як постійний рух від одного об'єкта до іншого, Гоббс наголошує, що тут часто йдеться про перевагу такої загальної людською схильності, як «вічне й невпинне бажання дедалі більшої й більшої влади, бажання, що його уриває тільки смерть» [8, с. 132].

I найістотніше - яка ж головна причина такої схильності? Йдеться, на думку Гоббса, не так про прагнення дедалі більшої насолоди, якою супроводжується влада, як про те, що більша і більша влада убезпечує належний рівень вже існуючої влади та добробуту. А людей безправних до покори владі спонукає прагнення спокою та захисту. Більше того, «страх зазнати утисків примушує людину заздалегідь шукати допомоги суспільства, бо не існує іншого шляху для збереження людиною свого життя і свободи» [8, с. 135]. Уже тут Гоббс окреслює перехід від антропологічної складової до теорії угоди, чому особливо мають слугувати його тлумачення влади. Зауважимо, що тлумачення Гоббсом влади є досить однозначним: йдеться не просто про необмежене прагнення матеріальних благ, останні стають приналежними до феномена влади, коли розпочинається їх розподіл серед численних друзів та слуг.

«Природа зробила людей рівними у здібностях тіла і розуму, і якщо навіть інколи і знайдеться хтось, тілом набагато міцніший або розумом швидший за всіх інших, усе ж таки на загал ця відмінність однієї людини від іншої не така значна, щоб одна якась людина могла на цій підставі претендувати на якесь благо для себе, на яке так само не могла б претендувати й інша людина» [8, с. 150151] і найслабша може вбити найсильнішого, об'єднавшись 3 іншими людьми. Продовжуючи свої розмисли, Гоббс наголошує на тому, що рівність стає засадою недовіри, а остання вмотивовує прагнення влади: «Через цю невпевненість одне в одному ніхто немає розумнішого засобу охоронити себе, ніж запобіжними заходами, тобто силою та хитрістю, утримувати у покорі тих, кого можна, доти, доки не побачить він іншої влади, достатньо потужної, щоб становити для нього небезпеку» [8, с. 151]. 
Тож, люди відчувають велику гіркоту від перебування в суспільстві без влади, а в самій природі людини ми знаходимо, на думку Гоббса, суперництво, невпевненість та прагнення слави. «Звідси очевидно, що впродовж того часу, коли люди живуть без загальної влади, яка б усіх тримала у страху, вони перебувають у становищі, яке називається війною, і це війна всіх проти всіх» [8, с. 153], якій властиві не лише застій в усіх сферах суспільного життя, а насамперед - постійний страх і небезпека насильницької смерті, що перетворює життя людини на самотнє, бідне й коротке. Проте означений постійний страх і небезпека насильницької смерті та прагнення спокійного життя роблять людей не лише схильними до миру, але окреслюють засади мирної угоди. Для розуміння цих засад Гоббс знов звертається до визначення свободи як відсутності перешкод до вільного та розважливого використання влади. Саме 3 такого усвідомлення влади й виникає можливість подолання стану війни, здатність та необхідність для людини «відмовитись від свого права на всі речі й вдовольнитися тією мірою свободи у ставленні до інших людей, яку вона визнала б за іншими людьми стосовно себе. Бо доки кожен утримує за собою право робити все, що він забажає, доти всі люди перебувають у стані війни» [8, с. 156].

Таким чином, описуючи природний стан через констатацію прагнення (рівних щодо насильницької смерті) людей до самозбереження, щастя та влади, Гоббс наголошує - слово є занадто слабким приборкувачем людських пристрастей і не може аж ніяк порівнятися зі страхом перед сильною, уповноваженою на примус владою. Через цю слабкість одного лише слова для примусу людей до виконання своїх угод, у людській природі існує, наголошує Гоббс, лише два засоби посилити останній: «По-перше, страх людини щодо наслідків порушення нею свого слова; по-друге, бажання слави чи гордість, яка виявляє себе відсутністю в людини навіть потреби порушувати своє слово» [8, с. 165].

Лише в контексті укладеної угоди можна говорити про справедливість та несправедливість. А актуалізує означені поняття не лише укладення та дотримання угод, а й вихід з природного стану та заснування держави. «Ось чому перш, ніж слова справедливе та несправедливе можуть означитись, повинна бути якась примусова 
влада, яка завдяки страху перед покаранням більшим, ніж користь, очікувана людьми від порушення своєї угоди, присилувала б їх рівною мірою до виконання своїх угод й утвердила власність, яку люди за взаємним договором отримують як компенсацію за те універсальне право, якого вони зрікаються. Така влада може з'явитись завдяки заснуванню держави» [8, с. 167]. Остання стає власне засадничою для власності та справедливості: «Отже, природа справедливості полягає в дотриманні дійсних угод, але дійсність угод починається лише 3 настановленням цивільної влади, достатньої для того, аби примусити людей дотримуватися своїх угод, і це також початок власності» [8, с. 167].

Гоббс також стверджує, що основні принципи суспільної угоди та прагнення людини діяти справедливо та неупереджено випливають не з безумовно-загальних структур розуму, а з умовнокатегоричної, конвенційної згоди на відмову, заборону брати участь у згубному загальному соціальному конфлікті. Більше того, заснований на такій згоді принцип справедливості не є власне метафізичним, універсалізуючим справедливість, а лише тимчасовим принципом, який потребує (для його ж дотримання) подальшої державно-політичної легітимації. Тож завдяки Т. Гоббсу була сформульована важлива для здійснення справедливості настанова модерного світу - взаємна відмова від свободи має відбуватися в певних, спільно визнаних межах. На цю, швидше правову, а не моральну силу суспільної угоди звертає увагу О. Гьофе у своїй праці «Політична справедливість» [9]. Він починає з аналізу відмінності угоди від звичайної неформальної обіцянки дотримуватися обіцяного. Суспільна угода є договором, якому притаманні такі важливі (особливо в контексті проблеми свободи та справедливості їі обмежень) риси: «по-перше, іiі за учасниками залишається право вільно обирати, будуть вони приєднуватися до угоди чи ні. По-друге, за умов угоди йдеться про передавання певних прав та обов'язків, яке, найчастіше, має риси взаємності. I, зрештою, по-третє, після досягнення угоди дотримання іiі умов стає правовим обов'язком кожного учасника, а недотримання призводить до застосування відповідних штрафних санкцій. Підсумовуючи сказане, можна стверджувати, що за своєю природою угода - це добровільне та здебі- 
ISSN 2078-8142 Multiversum. Philosophical almanac. 2021. Issue 2(174). Vol. 1.

льшого взаємне обмеження свободи, яке має правову силу» [9, с. 281-282].

Як же Гоббс відповідає на питання про те, що означає бути вільною людиною? «Відповідно до власного і загальноприйнятого значення слова, вільна людина - це та, котрій ніщо не перешкоджає робити бажане, бо за своїми фізичними і розумовими здібностями вона здатна це робити. Але застосовувати слово свобода до речей, які не є тілами, - це зловживання словом, адже те, що не має здатності рухатися, не може зустрічати опору. Тому, коли (наприклад) кажуть, що дорога вільна, мають на увазі свободу не дороги, а тих людей, які по ній рухаються без перешкод» [8, с. 216]. Іншими словами, продовжує Гоббс, свобода людини полягає в тому, що вона чинить так, як вказують ій іiі воля та бажання. До того ж, на його думку, страх і свобода є також сумісними, а дії людини зі страху перед законами є також добровільними, бо вона може від них утриматися.

Щоправда, вже Д. Г’юм, розпочинаючи критичне осмислення модерного контрактуалізму, вважав дещо наївними розмисли про те, що владні структури встановлюються лише шляхом згоди. На його думку, обов'язковість суспільних приписів можливо й мала спочатку договірну природу, проте згодом поступово втрачає іï, здобуваючи самостійної, незалежної від домовленостей сили. Г’юм застерігає проти небезпеки встановлення необмеженої влади правителя та наполягає: лише на засадах загальних та обов'язкових для всіх законів можна оберігати життя та власність кожної людини. Саме цю (полемічно спрямовану проти Гоббса) ідею верховенства права над легітимованою волею правителя послідовно обстоював Ж.-Ж. Руссо. Тоді, коли Гоббс схиляється до переваг політичного ладу та «царства земного», Г’юм тяжіє до внутрішнього морального закону, що актуалізує його роздуми в контексті новітніх критичних дискурсів суспільної угоди (Е. Тугендгат, Дж. Грей, Е. Макінтайр, Т. Парсонс та ін.) та конвенційного тлумачення природи і сутності моралі.

Таким чином, Гоббс прагнув усебічно осмислити вкорінені, на його думку, в залежності свободи від безпеки взаємини держави та громадянина, суверена та підданого, перетворюючи (але вже 
згодом, через творчість Локка та Руссо) ландшафти спотвореного егоїстичним інтересом політичного буття на залюднений справедливий політичний простір. Бо саме останній тяжіє до внутрішнього морального закону та надає перевагу тлумаченню державного ладу як вільного, а не відчуженого підпорядкування індивідів певному верховному моральному закону, який отримує назву загальної волі: дотримуюсь такої угоди, індивіди перебирають на себе відповідальність керуватися у свої діях лише розумом. Тож варто наголосити, що моральність людини та ії добре ставлення до інших людей зумовлене взаєминами рівності та солідарності, і навпаки - в нерівних умовах суспільного буття люди перетворюються на атомарних егоїстів.

Глибокі трансформації та кризові явища сучасного суспільства знов і знов актуалізують осмислення місця і ролі суспільної угоди в сучасному соціумі. Особливої актуальності їі новітні, часто-густо критичні, спрямовані на розуміння евристичного сенсу та меж сучасного контрактуалізму набувають для країн пострадянського простору, які прагнуть розбудови своїх держав як правових та демократичних. Адже демократія, принаймні в найістотнішому іiі визначенні, це не що інше, як влада, заснована на суспільній угоді. До того ж, дедалі більш нагальним постає прагнення поєднати емпіричний та нормативний виміри сучасної соціальної та політичної філософії, подолати глибоку прірву між філософськими дискурсами та реальним буттям і відшукати відповідь на запитання про реальні та гідні шляхи виходу з описаного Т. Гоббсом стану «війни всіх проти всіх» та знецінення заснованих на свободі та мужності моральних чеснот, соціальної справедливості загалом.

Безперечно, що така бажана та важко досяжна наявність спільного інтересу та заснована на взаємній довірі згода допоможе людям (краще будь-якого контракту) діяти злагоджено для досягнення спільної мети. І для того, щоб залишитися в просторі справедливості та моралі, потрібно не лише звільнитися від формальних угод та замінити їх угодами реальними, а й дотримуватися цих угод. Завдяки Гоббсу набуло значущості розуміння ролі суспільної угоди не лише для конституювання держави, а й для подальшого іiі функціонування як спільноти громадян, які мають можливість вільно жити та обговорювати актуальні суспільні проблеми. Отже, 
вкорінений у філософії людини принцип суспільної угоди актуалізує не лише проблему справедливості, а й проблему свободи та проблему верховенства права як істотного морально-правового способу існування сучасного суспільства.

Дослідження філософії свободи Т. Гоббса уможливлює наступні висновки. По-перше, Гоббс постійно наголошував на тому, що причини порушення суспільної угоди та ворожнечі між людьми вкорінені в самій природі людини та можуть бути виокремленні в якості наступних трьох причин: конкуренція, недовіра та марнославство. Саме відсутність довіри призводить до насильства та несправедливих домагань життя та власності інших людей. До цього долучається і прагнення, також у будь-який спосіб, більшої поваги та визнання. За відсутності довіри люди постають одне для одного не як громадяни, рівноправні учасники суспільної угоди, а як обтяжені недовірою конкуренти. Особливої актуальності філософії Гоббса надають його глибокі, сповнені інтелектуальної мужності роздуми про людину та іiі суспільне буття: нехай у державі «буде скільки завгодно людей, але якщо кожен з них керуватиметься лише особистими міркуваннями і прагненнями, то таке суспільство не може сподіватися на вбереження і захист ні від спільного ворога, ні від несправедливості, завдаваної в його межах один одному» [8, с. 185]. А страх перед ближнім буде руйнувати насамперед чуття внутрішньої безпеки, а потім і безпеки соціальної. I згода діяти людяно можлива лише завдяки силі, яка спрямовує дії людей у річище загального, спільного блага, насамперед - 3 метою убезпечення їх життя та здоров'я. Проте від цієї тези Гоббс зробив наступний, ще малодосліджений крок.

По-друге, і найістотніше, вже з часів Гоббса, завдяки Гоббсу, було окреслено низку свобод підданих, які не заборонені законом: свобода господарювати, торгувати, одружуватися, виховувати дітей, обирати місце проживання. Люди, за Гоббсом, вільні робити те, що розважливо вважають за найвигідніше для них. Важливість для Гоббса цих переважно господарських свобод зумовлена тим, що на їх обширах виникає, проступає можливість формування прав та свобод вже не підданих, а громадян. Саме така можливість жити власним розумом, мати власність, права стає засадою суспільної 
угоди в тлумаченні не лише Гоббса, а й Руссо. Проте для поглиблення цієї Гоббсової інтелектуальної інтуїції варто було зробити наступний крок: вважати, уявляти людей добрими і милосердними, надати їм (а не лише переважно державі) необхідні права і свободи, обмежити владу держави навіть тоді, коли вона слугує безпеці своїх громадян. Але навіть такі кроки в бік демократії не додали Руссо оптимізму та не зробили його роздуми в цьому річищі сильнішими за здогадки Гоббса. Осердям же останніх було прагнення (розвинуте згодом I. Кантом в його роздумах про природу Просвітництва) захистити «свободу підданих» як здатність користуватися власним розумом.

\section{ЛІТЕРАТУРА}

1. Habermas J. Vernünftige Freiheit. Spuren de Dikurses über Glauben und Wissen. Auch eine Geschichte der Philosophie. Bd. 2. Berlin, 2019.

2. Höffe O. Geschichte des politischen Denkens. München, 2016.

3. Honneth A. Das Recht der Freiheit. Grundriß einer demokratischen Sittlichkeit. Berlin, 2011.

4. Apeldoorn L. On the person and office of the sovereign in Hobbes' Leviathan [Virtual Resource]. British Journal for the History of Philosophy. 2019. № 28(1), 49-68.

5. Höffe O. Thomas Hobbes. München, 2010.

6. Höffe O. Sieben Thesen zur Anthropologie der Menschenrechte. Mensch - ein politisches Tier? Essays zur politischen Anthropologie. Stuttgart. 1992. P. 188-211.

7. Kersting W. Politische Philosophie des Gesellschaftsvertrags. Darmstadt, 1996.

8. Гоббс Т. Левіафан, або Суть, будова і повноваження держави иерковної та цивільної. К. : Дух і Літера, 2000.

9. Хеффе О. Политика, право, справедливость. Основоположения критической философии права и государства. М.: Гнозис, 1994. 


\section{REFERENCES}

Habermas, J. (2019). Vernünftige Freiheit. Spuren de Dikurses über Glauben und Wissen. In: Auch eine Geschichte der Philosophie. Bd. 2. Berlin..

Höffe, O. (2016). Geschichte des politischen Denkens. München.

Honneth, A. (2011). Das Recht der Freiheit. Grundriß einer demokratischen Sittlichkeit. Berlin.

Apeldoorn, L. (2019). On the person and office of the sovereign in Hobbes' Leviathan. British Journal for the History of Philosophy, 28(1), 49-68. DOI: https://doi.org/10.1080/09608788.2019.1613632.

Höffe, O. (2010). Thomas Hobbes. München.

Höffe, O. (1992). Sieben Thesen zur Anthropologie der Menschenrechte. In: Mensch - ein politisches Tier? Essays zur politischen Anthropologie. Stuttgart. P. 188-211.

Kersting, W. (1996). Politische Philosophie des Gesellschaftsvertrag. Darmstadt.

Hobbes, T. (2000). Leviathan. Kyiv: Duch i Litera, 2000. [In Ukrainian].

Höffe, O. (1994). Political Justice: Foundations for a Critical Philosophy of Law and the State. M.: Gnosis. [In Russian].

\section{Dmytro Usov}

Doctor of Philosophical Sciences, Professor, Cherkasy Institute of Fire Safety named after Chornobyl Heroes of National University of Civil Protection of Ukraine; Cherkasy, Ukraine; e-mail: dimausov@i.ua; ORCID: https://orcid. org /0000-0002-8898-9743

\section{Thomas Hobbes's philosophy of freedom: basic components and modern contexts}

\section{Abstract}

The author of the article proceeds from the fact that the philosophy of Thomas Hobbes is still relevant today. Life itself in the age of "virusocracy", the struggle for both security and freedom, needs answers to the question of the rela- 
tionship between rights, freedom, fear, security, which is, the problems to which Thomas Hobbes constantly addressed. These aspects of Hobbes's philosophical heritage will be the subject of this article and deepen the thoughts of domestic researchers about the meaning of the idea of Hobbes's social contract through the consistent reconstruction of its still little-studied algorithms for forming a just rule of law, the relationship between the person and the state. To be specific, it is from the political philosophy of Hobbes that the profound shift in understanding human nature and freedom inherent in modern political philosophy and the philosophy of law in general begins. Proposed by Hobbes political anthropology is based on the thesis of the natural equality of people, as well as on the desire to justify the need for individuals to realize the restrictions on their own selfishness and freedom for the collective will of other citizens. It also goes about the relevance for modern philosophy and our domestic social space Hobbes developed the principle of social contract as a new social principle of regulation of human existence, which embodied a significant transition from teleological to legal ideas about the personality, its freedom and justice. In the political philosophy of T. Hobbes developed the idea of internal disobedience, freedom of conscience as "human and civil rights", that the government must recognize, not just allow personal independence of its citizens, their right to live and act on their own. However, for the further development of this idea it was necessary to go beyond the philosophy of T. Hobbes, which was J.-J. Rousseau destined to do.

Keywords: T. Hobbes, political philosophy, theory of social contract, freedom, security, fear, civil society, J.-J. Rousseau. 